\title{
Hubungan Tingkat Kejadian Efek Samping Antiinflamasi Non Steroid dengan Usia dan Jenis Kelamin
}

Keni Idacahyati ${ }^{1 *}$, Tita Nofianti ${ }^{1}$, Geby Alinda Aswa ${ }^{1}$, Maritsa Nurfatwa ${ }^{2}$

${ }^{1}$ Departemen Farmakologi dan Farmasi Klinik, STIKes Bakti Tunas Husada, Tasikmalaya

${ }^{2}$ Pusat Penelitian Bioteknologi LIPI, Cibinong, Bogor

*Corresponding author: keniida@stikes-bth.ac.id

Submitted: 11 Desember 2019

Accepted: 13 Februari 2020

Published: 29 Februari 2020

\begin{abstract}
Background: Non steroid antiinflamatory drug (NSAIDs) are used to reduce chronic pain and inflammation disease. NSAIDs can inhibit the enzymes cyclooxygenase-1 and cyclooxygenase-2, thereby reducing prostaglandin and prostacyclin production. The side effects of NSAIDs are the GI complications, cardiovascular events and renal disturbances. Objective: This study aimed to determine the adverse drug reaction of NSAIDs and to see the relationship between the incidence of Adverse Drug Reaction (ADR) with age and sex in selfmedication patients in Tasikmalaya City. Methods: This observational study was conducted prospectively from February till May 2019. A purposive sampling in 52 respondent was done. The Naranjo Algorithm was used a data collection toll to assess relationship between an identified untoward clinical event and a drug. The inclusion criterias was respondents aged 18 years old and above who used NSAIDs. Exclusion criteria were pregnanct women, and responden who were prescribed with NSAIDs. A Spearman correlation test was done to analyse the data. Results: The results showed that 13 from 52 participant experience ADR from using NSAIDs nausea, the stomachache, increased blood pressure and melena. There was a significant relationship between the incidence of $A D R$ with age $(p=0.001)$ and there was no significant relationship between the incidence of $A D R$ with gender $(p=0.155)$ (OR: 0.657). Conclusions: ADR that occurs in respondents is related to age but there is no relationship with gender.
\end{abstract}

Keywords: adverse drug reaction, naranjo, NSAID, side effect

\begin{abstract}
Abstrak
Pendahuluan: Non steroid antiinflamasi drugs (NSAIDs) digunakan dalam mengatasi nyeri kronis dan inflamasi. NSAIDs menurunkan produksi prostaglandin dan prostasiklin dengan cara menghambat enzim siklooksigenase 1 dan siklooksigenase 2. Efek samping NSAIDs dapat menyebabkan gangguan di gastrointestinal, penyakit kardiovaskular, dan gangguan fungsi ginjal. Tujuan: Penelitian ini bertujuan untuk mengetahui kejadian adverse drug reaction obat golongan NSAIDs dan melihat hubungan antara kejadian ADR dengan usia dan jenis kelamin pada pasien swamedikasi di Kota Tasikmalaya. Metode: Penelitian ini dilakukan secara observasional dan prospektif yang dilakukan di 2 Apotek Kota Tasikmalaya pada bulan Februari - Mei 2019. Metode purposif sampling dilakukan untuk pengambilan sampel dengan jumlah sampel 52 responden. Instrumen pengambilan data menggunakan Algoritma Naranjo untuk mengidentifikasi apakah terdapat hubungan antara gejala klinik yang tidak diinginkan dengan obat yang digunakan menggunakan kuesioner untuk mendapatkan skor probabilitas. Kriteria inklusi dalam penelitian ini adalah responden yang mengkonsumsi NSAIDs dengan usia lebih dari 18 tahun, kriteria eksklusi adalah wanita hamil dan responden dengan penggunaan obat golongan NSAIDs menggunakan resep dokter. Analisis data secara statistik menggunakan uji korelasi Spearman. Hasil: Hasil penelitian menunjukan dari 52 pasien swamedikasi terdapat 13 orang (25\%) mengalami ADR obat golongan NSAIDs berupa mual, sakit di bagian lambung, tekanan darah meningkat dan melena. Hasil analisis statistik menunjukan terdapat hubungan kuat antara kejadian ADR dengan usia $(\mathrm{p}=$ $0,001)$ dan tidak adanya hubungan antara kejadian ADR dengan jenis kelamin $(p=0,155)(\mathrm{OR}: 0,657)$.
\end{abstract}


Kesimpulan: ADR yang terjadi pada responden berhubungan dengan usia tetapi tidak terdapat hubungan dengan jenis kelamin.

Kata kunci: efek samping, adverse drug reaction, naranjo, NSAID, anti inflamasi

\section{PENDAHULUAN}

Salah satu obat yang sering digunakan dalam mengatasi inflamasi adalah NSAIDs (IRA, 2014). NSAID bekerja dengan cara menghambat enzim siklooksigenase 1 dan 2 sehingga produksi prostaglandin (PGE2) dan prostasiklin (PGI2) yang merupakan mediator inflamasi yang mengakibatkan terjadinya vasokonstriksi pembuluh darah dapat menurun. Penggunaan NSAIDs ini dapat berdampak pada timbulnya beberapa efek samping dan komplikasi seperti gangguan fungsi ginjal, edema, hipertensi, dan pendarahan di gastrointestinal (Lovell \& Ernst, 2017). Salah satu masalah yang berkaitan dengan penggunaan obat adalah Adverse Drug Reactions (ADR). ADR adalah reaksi obat yang tidak diinginkan yang terjadi selama penggunaan klinis. Reaksi obat yang merugikan terjadi hampir setiap hari di institusi perawatan kesehatan dan dapat mempengaruhi kualitas hidup pasien secara negatif, seringkali menyebabkan morbiditas dan mortalitas yang cukup tinggi. Penelitian yang dilakukan pada 1000 pasien di RS Singapura menyebutkan bahwa $12,4 \%$ pasien mengalami ADR terkait dengan pemberian obat cardiovascular (Chan dkk., 2016). ADRs yang terjadi pada penggunaan NSAIDs sebanyak $12 \%$ (Komagamine \& Kobayashi, 2019). ADR yang banyak ditemukan pada penggunaan NSAIDs yaitu sebanyak 56,7\% merupakan gangguan pada gastrointestinal seperti dispepsia, diare, konstipasi, mual, muntah, dan gastritis dan 16,7\% ganguan pada kardiovaskular seperti hipertensi dan hipotensi (Rahmawati dkk., 2008). ADR yang terjadi pada pasien muskuloskeletal yang mengkonsumsi NSAIDs sebanyak $12 \%$ mengalami gangguan gastrointestinal (Koffeman dkk., 2015). Ibuprofen dan naproxen dosis rendah merupakan NSAIDs yang mungkin meningkatkan resiko penyakit kadiovaskular (McGettigan \& Henry, 2011). NSAID juga merupakan obat yang paling banyak menyebabkan pasien dirawat karena mengalami ADR (Christianie dkk., 2008).

Obat-obatan yang menyebabkan ADR sering ditemui pada populasi pasien dengan resiko tinggi (Camargo dkk., 2009). Penelitian ini bertujuan untuk mengetahui gambaran ADR obat golongan NSAID dan melihat hubungan antara kejadian ADR dengan usia dan jenis kelamin pada pasien swamedikasi di apotek Kota Tasikmalaya.

\section{METODE}

Penelitian ini dilakukan secara observasional yang bersifat prospektif dengan pengambilan data menggunakan algoritma Naranjo dan formulir informasi pasien mengenai ADR obat golongan NSAID di 2 apotek Kota Tasikmalaya pada bulan Februari - Mei 2019. Teknik pengambilan sampel pada penelitian ini dilakukan berdasarkan teknik purposive sampling. Kriteria inklusi pasien yang melakukan swamedikasi obat golongan NSAID pada bulan Februari - Mei 2019, berusia lebih dari 18 tahun. Kriteria eksklusi wanita hamil dan pasien dengan penggunaan obat golongan NSAID menggunakan resep dokter. Penelitian ini telah mendapatkan persetujuan etik dari komisi etik penelitian UNPAD Nomor: 269/UN6.KEP/EC/2019. Data dianalisis menggunakan SPSS uji Spearman untuk mengetahui hubungan kejadian ADR dengan jenis kelamin dan usia.

\section{HASIL DAN PEMBAHASAN}

Tabel 1 menunjukkan bahwa terdapat lebih banyak pasien yang melakukan swamedikasi obat golongan NSAID dengan jenis kelamin perempuan yaitu sebanyak $28(54 \%)$ pasien dari total 52 (100\%). Prevalensi nyeri pada perempuan lebih besar dibandingkan dengan laki-laki sehingga penggunaan NSAID lebih banyak pada perempuan (Larsson dkk., 2017).

Tabel 1. Klasifikasi pasien yang mengkonsumsi NSAID berdasarkan jenis kelamin dan usia

\begin{tabular}{lcc}
\hline \multicolumn{1}{c}{ Demografi } & $\begin{array}{c}\text { Jumlah } \\
\text { Pasien }\end{array}$ & Persentase \\
\hline Jenis Kelamin & & \\
Laki-laki & 24 & $46 \%$ \\
Perempuan & 28 & $54 \%$ \\
Usia (Tahun) & & \\
18 - 30 (Remaja) & 18 & $35 \%$ \\
$31-45$ (Dewasa) & 20 & $38 \%$ \\
46-60 (Paruh & 14 & $27 \%$ \\
Baya) & & \\
\hline
\end{tabular}


Distribusi pasien yang mengkonsumsi obat Tasikmalaya pada bulan Februari - Mei 2019, sebanyak 52 pasien dengan pasien termuda berumur 19 tahun dan pasien tertua berumur 59 tahun. Pembagian usia dimulai dari 18 tahun, sesuai dengan subyek penelitian. Pengelompokan pasien tersebut dilakukan untuk mengetahui pada rentan berapakah kejadian ADR pada pasien dengan penggunaan obat golongan NSAID banyak terjadi.

Berdasarkan hasil penelitian terhadap 52 responden, adanya ADR obat golongan NSAID dirasakan oleh 13 pasien. ADR yang mungkin terjadi akibat penggunaan obat golongan NSAID yaitu mual, rasa perih di lambung, feses hitam (melena), dan meningkatnya tekanan darah. Setiap gejala dan keluhan setelah mengkonsumsi NSAID pasien dianjurkan untuk melaporkan kepada petugas apotek di apotek Kota Tasikmalaya.

Berdasarkan Tabel 2, perempuan lebih banyak mengalami ADR yaitu sebanyak 8 orang (62\%) dibandingkan dengan pasien laki laki sebanyak 5 orang (38\%). Beberapa studi telah menemukan, bahwa wanita lebih berpotensi mengalami ADR dibandingkan dengan pria karena wanita lebih sensitif terhadap reaksi obat (Davies dkk., 2011).

Tabel 2. Prevalensi kejadian ADR berdasarkan jenis

\begin{tabular}{ccc}
\multicolumn{3}{c}{ kelamin dan usia } \\
\hline Jenis kelamin & $\begin{array}{c}\text { Jumlah } \\
\text { pasien }\end{array}$ & Persentase \\
\hline Laki-laki & 5 & $38 \%$ \\
Perempuan & 8 & $62 \%$ \\
\hline Usia & & \\
\hline $18-30$ & 0 & 0 \\
$31-45$ & 5 & $38 \%$ \\
$46-60$ & 8 & $62 \%$ \\
\hline
\end{tabular}

Kejadian ADR yang paling banyak terjadi pada umur 32 - 59 tahun dengan jumlah pasien 13 (25\%). Klasifikasi pasien swamedikasi yang mengalami ADR obat golongan NSAID berdasarkan usia di apotek Kota Tasikmalaya terdapat pasien pada usia kategori dewasa sebanyak $5(38 \%)$ orang dan paruh baya sebanyak 8 (62\%) orang.

Dalam hal ini menunjukan adanya peningkatan kejadian efek samping obat dengan bertambahnya usia. Semakin bertambah usia maka kemampuan fungsi hati terutama peran enzim CYP 450 dalam metabolisme obat menurun serta kemampuan untuk mengeliminasi obat juga menurun sehingga beresiko besar untuk golongan NSAID dengan kategori usia di apotek Kota mengalami efek samping obat. Disamping itu, pada usia tua kejadian efek samping obat lebih banyak terjadi hal ini disebabkan karena semakin meningkatnya usia proses metabolisme akan semakin lambat sehingga clearance hepar, aktivitas enzimatik, dan ketersedian kofaktor endogen yang membantu metabolisme obat menurun (Reni dkk., 2016)

Pada usia tua terjadi perubahan fungsi anatomi dan fisiologi manusia, seperti kehilangan unit fungsional organ yang mengakibatkan obat didalam tubuh tidak dapat bekerja secara maksimal. Perubahan penanganan tubuh terhadap obat juga dapat mengakibatkan perubahan dalam respon farmakodinamika (Davies dkk., 2011).

Berdasarkan Tabel 3 terdapat hubungan antara kejadian ADR obat golongan NSAIDs dengan usia, dari data diatas diperoleh nilai korelasi sig (2-tailed) sebesar 0,001 atau < 0,05. Dapat diartikan bahwa semakin tinggi usia maka semakin besar kemungkinan terjadi ADR obat golongan NSAID.

Tabel 3. Gejala ADR responden berdasarkan usia

\begin{tabular}{|c|c|c|c|}
\hline $\begin{array}{c}\text { Usia } \\
\text { (Tahun) }\end{array}$ & Nama Obat & ADR & $\begin{array}{c}P \\
(p<0.05)\end{array}$ \\
\hline & Asam & & \\
\hline 32 & $\begin{array}{c}\text { Mefenamat } \\
\mathrm{Na}\end{array}$ & GI & \\
\hline 34 & Diklofenak & Mual & \\
\hline 35 & Meloxicam & Mual & \\
\hline 35 & Ibuprofen & Mual & \\
\hline 36 & Meloxicam & GI & \\
\hline & & TD & \\
\hline 47 & Etoricoxib & meningkat & \\
\hline 47 & Piroxicam & $\begin{array}{l}\text { GI } \\
\text { TD }\end{array}$ & 0,001 \\
\hline 49 & Celecoxib & $\begin{array}{c}\text { meningkat } \\
\text { TD }\end{array}$ & \\
\hline 50 & $\begin{array}{c}\text { Etoricoxib } \\
\text { Asam }\end{array}$ & meningkat & \\
\hline 57 & Mefenamat & $\begin{array}{r}\text { GI } \\
\text { TD }\end{array}$ & \\
\hline 57 & Etoricoxib & meningkat & \\
\hline 58 & Piroxicam & GI & \\
\hline 59 & Piroxicam & Melena & \\
\hline
\end{tabular}

Tabel 4 menunjukkan tidak terdapat hubungan antara kejadian ADR obat golongan NSAIDs dengan jenis kelamin, dengan perolehan nilai korelasi sig sebesar 0,155 ( $\mathrm{p}>0,05)$. Jenis kelamin pria ataupun wanita tidak berbeda signifikan dalam mengalami kejadian ADR obat golongan NSAIDs. 
Tabel 4. Hubungan kejadian ADR obat golongan NSAID dengan jenis kelamin

\begin{tabular}{cccc}
\hline JK & Nama Obat & ADR & $\begin{array}{c}\text { Sig } \\
(\mathrm{p}<0.05)\end{array}$ \\
\hline $\mathrm{P}$ & Asam Mefenamat & GI & \\
$\mathrm{P}$ & Na. Diklofenak & Mual & \\
$\mathrm{L}$ & Meloxicam & Mual & \\
$\mathrm{P}$ & Ibuprofen & Mual & \\
$\mathrm{P}$ & Meloxicam & GI & \\
$\mathrm{P}$ & Etoricoxib & TD meningkat & 0,15 \\
$\mathrm{P}$ & Piroxicam & GI & \\
$\mathrm{L}$ & Celecoxib & TD meningkat & \\
$\mathrm{L}$ & Etoricoxib & TD meningkat & \\
$\mathrm{L}$ & Asam Mefenamat & GI & \\
$\mathrm{P}$ & Etoricoxib & TD meningkat & \\
$\mathrm{L}$ & Piroxicam & GI & \\
$\mathrm{P}$ & Piroxicam & Feses Hitam & \\
\hline
\end{tabular}

Keterangan: JK: jenis kelamin, P: perempuan, L: lakilaki

Pada Tabel 5 menunjukkan proporsi kejadian ADR. Jumlah total yang merasakan ADR yaitu 13 responden, terdapat 4 orang yang mendapat skor sebesar 6 (kemungkinan besar ADR/probable), 3 orang mendapat skor 7 (kemungkinan besar ADR/probable), 4 orang mendapat skor 8 (kemungkinan besar $\mathrm{ADR} /$ probable), dan 2 orang yang mendapat skor 9 (pasti ADR/difinite). NSAIDs dapat merusak mukosa lambung secara topikal dan sistemik. Prevalensi NSAIDs dapat menginduksi kerusakan lambung antara 10 - 25\% dan itu merupakan penyebab peningkatan morbiditas dan mortalitas. Golongan diklofenak paling banyak diresepkan dan paling tinggi mengalami ADR dengan presentase $73 \%$ (Gor \& Saksena, 2011). NSAIDs bersifat lipofilik dan asam, sehingga dapat menyebabkan kerusakan secara topikal, sedangkan efek sistemik NSAIDs disebabkan karena kerusakan mukosa yang terjadi akibat penurunan produksi prostaglandin. Produksi prostaglandin menurun juga dapat menyebabkan kerusakan lambung dan usus dua belas jari. Akibat penggunaan NSAIDs adalah gangguan fisiokimia pertahanan mukosa lambung dan inhibisi sistemik terhadap pelindung mukosa lambung melalui inhibisi aktivitas siklooksigenase (COX) mukosa lambung. NSAIDs bekerja menghambat sintesis prostaglandin (PG). Prostaglandin merupakan salah satu mediator inflamasi, pada saat prostaglandin dihambat mengakibatkan berkurangnya tanda inflamasi. Meskipun demikian, prostaglandin merupakan zat yang dapat melindungi mukosa saluran cerna atas. Penghambatan sintesis PG dapat menyebabkan berkurangnya ketahanan mukosa, yang menyebabkan iritasi dalam bentuk lesi akut mukosa lambung dengan bentuk ringan sampai berat. NSAIDs yang bersifat lipofilik dan asam mempermudah P-ISSN: 2406-9388 E-ISSN: $2580-8303$ trapping ion hidrogen masuk mukosa dan menimbulkan ulserasi (Amrulloh \& Utami, 2016).

Tabel 5. Proporsi kategori kejadian ADR

\begin{tabular}{lcc}
\hline Kategori kejadian ADR & Skor & Jumlah \\
\hline Definite $(9-13)$ & 9 & 2 \\
Probable $(5-8)$ & 8 & 4 \\
Probable $(5-8)$ & 7 & 3 \\
Probable $(5-8)$ & 6 & 4 \\
\hline
\end{tabular}

Terhambatnya enzim (COX-1 dan COX-2) mengakibatkan penurunan (PGE2) dan (PGI2) Penurunan produksi prostaglandin ini menyebabkan peningkatan retensi natrium. Peningkatan retensi natrium ini dapat menyebabkan komplikasi seperti hipertensi, gangguan fungsi ginjal, edema, dan pendarahan gastrointestinal. Peningkatan retensi natrium dapat menyebabkan peningkatan tekanan darah (Landefeld dkk., 2016; Lovell \& Ernst, 2017). Tekanan darah akan meningkat dengan umur yang semakin menua dan hipertensi (peningkatan tekanan darah secara persisten) sering terjadi pada umur yang semakin tua (Kosugi dkk., 2009).

Beberapa golongan obat yang dikenal dapat memberikan efek perdarahan atau meningkatkan resiko perdarahan diantaranya, obat golongan NSAIDs. Obat golongan NSAIDs yang dapat meningkatkan resiko perdarahan antara lain ketorolak, asam mefenamat, natrium diklofenak, kalium diklofenak, piroksikam, ibuprofen, ketoprofen, ketorolac, naproxen, indometasin (Kang dkk., 2011). Penelitian mengenai perdarahan pada saluran cerna mengakibatkan 54\% kematian dari 1225 kasus reaksi efek samping obat. Pasien dapat melihat manifestasi dari perdarahan berupa mimisan, perdarahan pada saluran cerna, feses hitam, ataupun berupa luka memar (Pirmohamed dkk., 2004).

Perdarahan terjadi saat pembuluh darah rusak yang menyebabkan darah keluar dari pembuluh darah. Ruptur organ dan pembuluh darah besar adalah contoh perdarahan internal (Lammers, 2009). Obat-obat NSAIDs seperti, ketorolak, piroksikam, asam mefenamat, natrium diklofenak secara tidak langsung diketahui dapat menyebabkan perdarahan pada saluran cerna hal ini berbeda dengan obat-obat dari golongan lain yang dapat menyebabkan perdarahan. Kerja obatobat NSAIDs yang tidak selektif dalam menghambat enzim siklooksigenase, penghambatan COX-1 pada pada mukosa lambung dapat menyebabkan perdarahan pada lambung. Piroksikam dan ketorolak merupakan 2 NSAIDs yang paling besar menimbulkan luka pada saluran percernaan (Lanas dkk., 2006). 
ADRs terjadi pada pemberian NSAIDs termasuk pendarahan gastrointestinal, efek terhadap jantung dan ginjal terlaporkan pada penelian sebelumnya (Moore dkk., 2015). Pada penelitian ini dilakukan hubungan kejadian ADRs dengan usia dan jenis kelamin, hal ini dilakukan untuk melihat faktor resiko yang mungkin terjadi pada pemberian NSAIDs.

Faktor resiko kejadian ADR NSAIDs adalah usia, riwayat penyakit tukak lambung, dyspepsia, penggunaan obat-obatan secara bersamaan seperti kortiksteroid dan antikoagulan, penggunaan NSAIDs dalam dosis tinggi dan penyakit kronis (Gor \& Saksena, 2011).

Keterbatasan yang terjadi dalam penelitian ini adalah sedikitnya jumlah sampel yang diambil karena keterbatasan watu penelitian dan tidak dilakukannya pengukuran konsentrasi obat dalam darah pada saat penentian ADR mengguna menggunakan algoritma naranjo.

\section{KESIMPULAN}

ADR yang terjadi pada responden berhubungan dengan usia tetapi tidak terdapat hubungan dengan jenis kelamin.

\section{UCAPAN TERIMAKASIH}

Terima kasih kepada Kemenristek Dikti yang telah membiayai penelitian ini dalam hibah penelitian dosen pemula.

\section{DAFTAR PUSTAKA}

Amrulloh, F. M. \& Utami, N. (2016). Hubungan Konsumsi OAINS terhadap Gastritis. Jurnal Majority; 5; 18-21.

Camargo, C. A., Rachelefsky, G. \& Schatz, M. (2009). Managing Asthma Exacerbations in the Emergency Department: Summary of the National Asthma Education and Prevention Program Expert Panel Report 3 Guidelines for the Management of Asthma Exacerbations. Proceedings of the American Thoracic Society; 6; 357-366.

Chan, S. L., Ang, X., Sani, L. L., Ng, H. Y., Winther, M. D., Liu, J. J., Brunham, L. R. \& Chan, A. (2016). Prevalence and Characteristics of Adverse Drug Reactions at Admission to Hospital: A Prospective Observational Study. British Journal of Clinical Pharmacology; 82; 1636-1646.

Christianie, M., Setiati, S., Trisna, Y. \& Andrajati, R. (2008). Kejadian Reaksi Obat yang Tidak
Dikehendaki yang Menyebabkan Pasien Usia Lanjut Dirawat di Ruang Perawatan Penyakit dalam Instalasi Rawat Inap B Rumah Sakit Dr. Cipto Mangunkusumo. Majalah Ilmu Kefarmasian; 5; 138-149.

Davies, G., Tenesa, A., Payton, A., Yang, J., Harris, S. E., Liewald, D., Ke, X., Hellard, S. L., Christoforou, A., Luciano, M., McGhee, K., Lopez, L., Gow, A. J., Corley, J., Redmond, P., Fox, H. C., Haggarty, P., Whalley, L. J., McNeill, G., Goddard, M. E., Espeseth, T., Lundervold, A. J., Reinvang, I., Pickles, A., Steen, V. M., Ollier, W., Porteous, D. J., Horan, M., Starr, J. M., Pendleton, N., Visscher, P. M., \& Deary, I. J. (2011). Genome-wide Association Studies Establish that Human Intelligence is Highly Heritable and Polygenic. Molecular Psychiatry; 16; 996-1005.

Gor, A. P. \& Saksena, M. (2011). Adverse Drug Reactions of Nonsteroidal Anti-inflammatory Drugs in Orthopedic Patients. Journal of Pharmacology and Pharmacotherapeutics; 2; 26-29.

Rekomendasi Perhimpunan Rheumatologi Indonesia (IRA). (2014). Penggunaan Obat Anti Inflamasi Non Steroid. http://reumatologi.or.id/var/rekomendasi. Accessed: 27 April 2019.

Kang, J. M., Kim, N., Lee, B. H., Park, H. K., Jo, H. J., Shin, C. M., Lee, S. H., Park, Y. S., Hwang, J. H., Kim, J. W., Jeong, S. H., Lee, D. H., Jung, H. C. \& Song, I. S. (2011). Risk Factors for Peptic Ulcer Bleeding in Terms of Helicobacter Pylori, NSAIDs, and Antiplatelet Agents. Scandinavian Journal of astroenterology; 46; 1295-1301.

Koffeman, A. R., Van Buul, A. R., Valkhoff, V. E., Jong, G. W. T., Bindels, P. J. E., Sturkenboom, M. C. J. M., Lei, J. D. V., Luijsterburg, P. A. J. \& Bierma-Zeinstra, S. M. A. (2015). Adverse Drug Reactions in a Primary Care Population Prescribed Non-steroidal Anti-inflammatory Drugs. Scandinavian Journal of Primary Health Care; 33; 163-169.

Komagamine, J. \& Kobayashi, M. (2019). Prevalence of Hospitalisation Caused by Adverse Drug Reactions at An Internal Medicine Ward of a Single Centre in Japan: A Cross-sectional Study. BMJ Open; 9; 1-7.

Kosugi, T., Nakagawa, T., Kamath, D. \& Johnson, R. J. (2009). Uric Acid and Hypertension: An Age- 
Related Relationship?. Journal of Human Hypertension; 23; 75-76.

Lammers, R. L. (2009). Roberts: Clinical Procedures in Emergency Medicine, 5th ed. Philadelphia: Saunders.

Lanas, A., García-Rodríguez, L. A., Arroyo, M. T., Gomollón, F., Feu, F., González-Pérez, A., Zapata, E., Bástida, G., Rodrigo, L., Santolaria, S., Güell, M., de Argila, C. M., Quintero, E., Borda, F. \& Piqué, J. M. (2006). Risk of Upper Gastrointestinal Ulcer Bleeding Associated with Selective Cyclo-oxygenase-2 Inhibitors, Traditional Non-aspirin Non-steroidal AntiInflammatory Drugs, Aspirin and Combinations. Gut; 55; 1731-1738.

Landefeld, K., Gonzales, H. \& Sander, G. E. (2016). Journal of Clinical Case Reports Hypertensive Crisis: The Causative Effects of Nonsteroidal Anti-Inflammatory Drugs. Journal of Clinical Case Reports; 6; 10-12.

Larsson, C., Hansson, E. E., Sundquist, K. \& Jakobsson, U. (2017). Chronic Pain in Older Adults: Prevalence, Incidence, and Risk Factors. Scandinavian Journal of Rheumatology; 46; 317-325.
Lovell, A. R. \& Ernst, M. E. (2017). Drug-Induced Hypertension: Focus on Mechanisms and Management. Current Hypertension Reports; 19; 39.

McGettigan, P. \& Henry, D. (2011). Cardiovascular Risk with Non-steroidal Anti-inflammatory Drugs: Systematic Review of Population-based Controlled Observational Studies. PLoS Medicine; 8.

Moore, N., Pollack, C. \& Butkerait, P. (2015). Adverse Drug Reactions and Drug-drug Interactions with Over-the-counter NSAIDs. Therapeutics and Clinical Risk Management; 11; 1061-1075.

Pirmohamed, M., James, S., Meakin, S. \& Green, C. (2004). Adverse Drug Reactions as Cause of Admission To Hospital: Authors' Reply. BMJ; 329; 15-19.

Rahmawati, F., Pramantara, I. D. P., Rochmah, W. \& Sulaiman, A. S. (2008). Adverse Drug Reactions (ADRs) in Geriatric Hospitalized Patients. Majalah Farmasi Indonesia; 19; 185-190.

Reni, Wahyono, T. Y. M. \& Yulismar. (2016). Kejadian Efek Samping Obat Anti Tuberkulosis pada Pasien Tuberkulosis. Jurnal Respirologi Indonesia; 36; 222-230. 